\title{
Trade Openness and Output Comovement in EU Emerging Countries: A Panel Data Approach
}

\author{
Bogdan Murarașu ${ }^{1}$ and Alina Bobașu ${ }^{2}$ \\ ${ }^{1}$ Faculty of Finance, Insurance, Banking and Stock Exchange, The Bucharest University of Economic \\ Studies, Bucharest, Romania \\ ${ }^{2}$ The Doctoral School of the Bucharest University of Economic Studies, Bucharest, Romania
}

Correspondence should be addressed to: Bogdan Murarașu; bogdan.murarasu@fin.ase.ro

Received date: 10 March 2013; Accepted date: 9 August 2014; Published date: 25 February 2015

Copyright @ 2015 . Bogdan Murarașu and Alina Bobașu. Distributed under Creative Commons CC-BY 4.0

\begin{abstract}
This paper analyses the impact of trade and financial openness on economic growth in case of some European Union emerging countries using static and dynamic panel data methods. The main findings indicate a positive effect of trade openness on GDP growth while the impact of financial linkages on output synchronization between emerging markets and European Union depends on the state of economy. The impact of financial linkages on output comovements during crises periods is different compared to normal economic states. In the latter case, between regions which know a high degree of financial linkages capital is directed where it is most productive generating output divergence. In opposition, during a crisis period of time, regions which are characterized by increased financial integration, especially through the banking system experience a significant intensification of their economic growth comovement. The impact of trade linkages is more reduced compared with the effect of financial linkages, in both states of the economy. In order to safeguard the benefits of financial and trade integration and to reduce the negative spillovers directed mainly from developed towards emerging economies during financial crisis is of the utmost importance to implement better prudential oversight and policy coordination.
\end{abstract}

Keywords: trade openness, financial linkages, European Union integration, panel data analysis

JEL Classification: E32, F36, F42, F43, F62

\section{Introduction}

The relationship between openness and economic growth has been a subject of much controversy in international macroeconomics literature. On the one hand, international trade plays a major role in the development of an economy by creating employment, and better living standards. Moreover, trade and financial openness during normal economic conditions have a positive impact on 
economic growth through productivity and technological innovations. On the other hand, the trade and financial linkages play a significant role in international transmission of common or idiosyncratic shocks (i.e. shocks that are countryspecific). The recent global economic crisis showed a significant increased comovement of world's economies and particularly of European Union countries. A significant debate in the related literature refers to the question whether output comovement across different regions increased as a result of financial globalization during the last decades.

The correlation between financial integration and the synchronization of economic activity depends on whether financial shocks to the banking sector or collateral shocks to firms dominate. If the economies experience a higher financially integration and the firms operating in certain countries are hit by negative shocks to their collateral, domestic and foreign banks reduce the lending in affected countries and increase lending in the nonaffected ones, amplifying this way the divergence of economic growth between these economies. However, if a negative shock is affecting the banking sector in a specific country with internationally operating banks, they will draw out capitals from all countries, transmitting the domestic banking shock internationally and generating a synchronized fall in output of all countries.

Preserving financial stability is essential in order to prevent synchronized GDP growth collapses regionally. The transmission mechanism of financial shocks on economic growth synchronization during normal periods is substantially different than during crisis. If during normal periods the capital flows are channelized towards emerging markets which offer greater yields determining output divergence between regions with strong financial linkages, during crisis the financial channels favours the propagation of shocks between financially linked regions contributing to output fall synchronization.
Therefore the goal of this article is twofold. Firstly it provides empirical evidence of the impact of two important measures of external openness, namely trade and financial linkages on economic growth in seven emerging economies from the Central and East Europe (CEE). Second, it depicts the role of trade and financial linkages in international transmission of common or idiosyncratic shocks, demonstrating that during crisis times they may significantly contribute to the synchronized output fall of emerging economies.

The paper is structured as follows: the next section presents the previous empirical works on how financial and trade linkages impact on economic growth. Section 3 describes data and methodology. Section 4 reports the panel estimates on the effect of financial and trade openness on economic growth. Section 5 and 6 analyse the role of financial and trade linkages in the transmission of shocks on output comovements. Section 7 concludes.

\section{Related Literature}

Most of the theoretical literature suggests that the degree of openness impacts economic growth in a positive manner. Therefore, Romer (1993), Grossman and Helpman (1991) argue that countries that are open catch more easily with developed economies. Also, Chang et al. (2005) state that open economies allocate their resources in a more efficient manner compared to closed ones. Frankel and Rose (1998) showed that the level of trade linkages on long term is significantly positive correlated with the degree of output synchronization.

There are also opinions stating that the effects of openness on economic growth are doubtful. For instance, Rodrik and Rodriguez (2001) state that the effects of openness on economic growth may have even negative impact. They carried out a very critical analysis of some empirical studied and concluded that in many cases the openness indicators were not appropriate measures or that the 
methodological choices the authors made had a strong impact on the results.

However, one major shortcoming that relates to most empirical studies is that very little attention has been paid to analysing the way international trade and financial openness may impact economic growth in emerging economies, and especially in case of Central and Eastern European countries (CEE countries). The way the market liberalisation and the increasing access of CEE countries to EU may or not have effects on economic growth is an issue well worth investigating.

Large economies originating shocks have significant effects on economic activity in emerging markets. The trade and financial linkages play a significant role in the transmission of these shocks. Claessens et al. (2012) show that financial shocks spread mostly through financial channels while, as Auerbach and Gorodnichenko (2013), Beetsma et al. (2006) argued that for fiscal policy shocks trade channels are more important that the other ones. $\mathrm{Di}$ Giovanni and Shambaugh (2008) argue that monetary policy shocks affect economic activity in foreign countries mostly through the interest rate channel.

Kalemli-Ozcan et al. (2013) analyse the impact of financial globalization on business cycle commovement using a proprietary database on banks' international exposure for industrialized countries for the time span between 1978 and 2009. Following the same methodology the present article runs a series of regressions, on quarterly data, using different measures for comovements between each CEE country and the EU in order to test the effects of financial and commercial linkages on output synchronization.

\section{Data and Methodology}

\section{Data}

The sample comprises seven Central and Eastern European economies: Czech Republic, Slovakia, Poland, Hungary, Bulgaria, Lithuania and Romania. To these add the European Union, which is the main trading and financial partner of these economies. Data for each country regarding real GDP, intra-EU trade volumes and foreign direct investments were obtained from Eurostat database at annual and quarterly frequencies. The ratio of inward FDI stock to GDP comes from the UNCTAD 2008 database. The data sample for the annual analysis initially covers the interval between 1991 and 2012, and it is afterwards reduced to more recent periods due to data limitations for additional variables which are included step by step in the empirical study; for the same reason Lithuania is excluded in the annual analysis.

There are several variables through which the degree of trade openness can be measure and they are divided into two categories: trade volume measures and trade restrictions measures. Since the last one is more difficult to quantify as it includes taxes on international trade, measures of trade barriers, etc. it is preferable to use a volume trade measure quantified by the ratio of exports plus imports to GDP which is usually known as trade share. As far as the financial openness is concerned, the ratio of FDI stock to GDP is used instead of the ratio of FDI flows to GDP due to the fact that spillovers may not be related to the current FDI inflows but to the ones which have accumulated along years. However, due to the data availability limitations in case of CEE countries, for the quarterly frequency analysis the flows of FDI to GDP ratio are used.

The main explanatory variables are the ratio of inward FDI stock to GDP, the ratio of trade to GDP to which add some other control variables, such as external demand and real effective exchange rate, which actually may play a significant role in emerging economies as CEE countries. The dependent variables are the economic growth and some different measures of the degree of synchronization between CEE countries and EU, which are described in the next sections. 
The impact of financial and trade linkages on output synchronization between CEE countries and EU is assessed using a balanced panel of seven pairs consisting of each CEE country included in the analysis and EU over the period Q1 2004 - Q3 2013. The panel estimates assess how the evolution of output synchronization is affected via trade and financial channels by common or idiosyncratic shocks.

\section{Methodology}

In order to assess the impact of trade openness on economic growth, static and dynamic panel data estimation methods are used, having the advantage that they allow exploiting time series but also cross sectional dimensions of data. The following equation is estimated:

$\Delta \mathrm{GDP}_{\mathrm{i}, \mathrm{t}}=\mathrm{c}_{\mathrm{it}}+\alpha_{1} \cdot \operatorname{trade}_{\mathrm{i}, \mathrm{t}}+\alpha_{2} \cdot \mathrm{fdi}_{\mathrm{i}, \mathrm{t}}+\alpha_{3} \cdot \operatorname{control}_{\mathrm{i}, \mathrm{t}}+\varepsilon_{\mathrm{i}, \mathrm{t}}$

where the dependent variable is the growth rate of GDP and the main explanatory variables are the shares of trade and FDI in GDP and some control variables that may have an impact on economic growth. The stationarity of the variables is validated by the IPS test proposed by Im et al. (2003) and a Fisher type test proposed by Maddala and $\mathrm{Wu}$ (1999). When estimating the equations, both fixed effects and random effects are considered in order to enable the control of individual country specific characteristics. To check the robustness of the results and discriminate between fixed and random

$\mathrm{H}=\left[\widehat{\beta}_{\mathrm{FE}}-\widehat{\beta}_{\mathrm{RE}}\right]^{\prime} \cdot\left[\operatorname{Var}\left(\widehat{\beta}_{\mathrm{FE}}-\widehat{\beta}_{\mathrm{RE}}\right)\right]^{-1} \cdot\left[\widehat{\beta}_{\mathrm{FE}}-\widehat{\beta}_{\mathrm{RE}}\right]$

where $\widehat{\beta}_{\mathrm{FE}}$ and $\widehat{\beta}_{\mathrm{RE}}$ are the estimators corresponding to the fixed and random effects models, the statistics having the null hypothesis that the random effects estimator is more efficient. A large value of the Hausman statistic indicates the rejection of the null hypothesis. The random effects model may also be evaluated individually by running the Breusch Pagan Lagrange multiplier test with the null hypothesis that the variances across entities are zero. The possible timeinvariant country fixed effects validated by the Hausman test are afterwards removed by using the first differenced Generalized Method of Moments (GMM) developed by Arrelano and Bond (1991).

$\mathrm{y}_{\mathrm{i}, \mathrm{t}}=\varepsilon_{\mathrm{t}}+\varepsilon_{\mathrm{i}, \mathrm{t}}+\sum_{\mathrm{j}} \rho_{\mathrm{i}, \mathrm{j}, \mathrm{t}} \cdot \varepsilon_{\mathrm{j}, \mathrm{t}}$ effects the Hausman test is used. The null hypothesis of the Hausman test is that the random effects estimator is more efficient, while the alternative hypothesis is that only the fixed effects estimator is consistent. The difference between the fixed effects and the random effects models is mainly ascribed to their assumption regarding how the heterogeneity is captured and also to the estimation method which is best suited. Fixed effects models require OLS while random effects models generally require GLS. In general, the Hausman statistics is:
Regarding the analysis of the effects that trade and financial linkages may have on GDP comovement, a slightly different methodology was employed. In order to evaluate the role of financial and trade linkages in transmitting the shocks originated during the economic global crisis, different correlations measures of output growth between each analysed country and the EU were regressed on the trade and financial linkages between them.

The growth rate of each country is assumed to be determined as: 
in which $\mathrm{y}_{\mathrm{i}, \mathrm{t}}$ denotes real economic growth in country $\mathrm{i}, \varepsilon_{\mathrm{t}}$ denotes common shocks, $\varepsilon_{\mathrm{i}, \mathrm{t}}$ represents domestic idiosyncratic shocks, $\varepsilon_{\mathrm{j}, \mathrm{t}}$ denotes the other regions' specific shocks, and $\rho_{\mathrm{i}, \mathrm{j}, \mathrm{t}}$ quantifies the correlation between each country and the EU within the analysed pair. Further, the analyses focus on standard linkages between different economies represented by the financial and trade channels.

Following Kalemli-Ozcan et al. (2013) the following regressions, on quarterly data, using different measures for comovements between each CEE country and the EU were run. The general form of the regression will be as following:

$\operatorname{Comv}_{\mathrm{i}, \mathrm{EU}, \mathrm{t}}=\mathrm{c}_{\mathrm{i}, \mathrm{EU}}+\alpha_{0} \cdot$ fin $_{\mathrm{i}, \mathrm{EU}, \mathrm{t}-1}+\beta_{0} \cdot$ trade $_{\mathrm{i}, \mathrm{EU}, \mathrm{t}-1}+$ crisis $_{\mathrm{t}}+\alpha_{1} \cdot$ fin $_{\mathrm{i}, \mathrm{EU}, \mathrm{t}-1} \cdot \operatorname{crisis}_{\mathrm{t}}+$

$+\beta_{1} \cdot$ trade $_{\mathrm{i}, \mathrm{EU}, \mathrm{t}-1} \cdot$ crisis $_{\mathrm{t}}+\varepsilon_{\mathrm{i}, \mathrm{EU}, \mathrm{t}}$

in which $\mathrm{Comv}_{\mathrm{i}, \mathrm{EU}, \mathrm{t}}$ is the economic growth rate correlation between country $\mathrm{i}$ and the EU in period $t$, fin $_{i, E U, t-1}$ and trade $e_{i, E U, t-1}$ denote the lagged financial and trade linkages between country $\mathrm{i}$ and the EU and crisis $_{\mathrm{t}}$ is a dummy variable which equals 1 during the crisis period. The dummy variable account for the effect of global crisis shocks that affected both output patterns and financial and trade integration. The specification also includes country pair fixed effects $c_{\mathrm{i}, \mathrm{EU}}$. This effects account for non-measurable factors such as strategic coordination of EU countries, cultural ties or other unobservable factors, all of which may have a significant effect output comovement.

The results of different version of the regression tested using the quarterly data for the sample from 2004 to 2013 are in line with those reported by Kalemli-Ozcan et al. (2013) and IMF (2013) at the global scale. The effect of finance shocks in a normal state of the economy is negative, but it becomes positive during the periods of crisis.

The sample included in the analysis, spanning the period between Q1 2004 and Q3 2013, comprises a crisis period, characterized by a major financial shock, between Q3 2008 and Q2 2009. The remaining of the time interval is considered normal period. The effect of trade and financial linkages are allowed to differ across the crisis and normal periods, since the shocks which affect the economic growth in each period are of different nature. During crisis period common shocks are more likely to manifest while during normal times the idiosyncratic shocks are more frequent. For this purpose a dummy variable which takes 1 during the crisis period and 0 elsewhere is included. Using the dummy variable it is possible to test whether the financial and trade channels work differently during normal and crisis periods.

\section{The Effects of Trade and Financial Openness on Economic Growth}

Most of today's macroeconomic literature point towards the fact that developing countries opening their economies to international trade and foreign direct investments would in time experience higher economic growth and therefore close the gap with respect to developed economies.

The CEE countries have imported a lot amount of capital and experienced high commercial and financial integration in order to catch up with developed economies. As part of the EU integration process these countries have adopted reforms and policies in order to liberalize their commercial and financial channels. Therefore the analysis of the main factors which have driven economic growth in CEE countries becomes a matter of high importance. Figure 1 depicts crosscorrelations between economic growth, on one hand, and trade and financial openness, on the other hand. The relation between economic growth and the two measures of openness seems to be a positive one. High openness lead to higher economic growth, although the magnitude of the relationship could be of course 
Figure 1: Economic growth and trade and financial openness in CEE countries
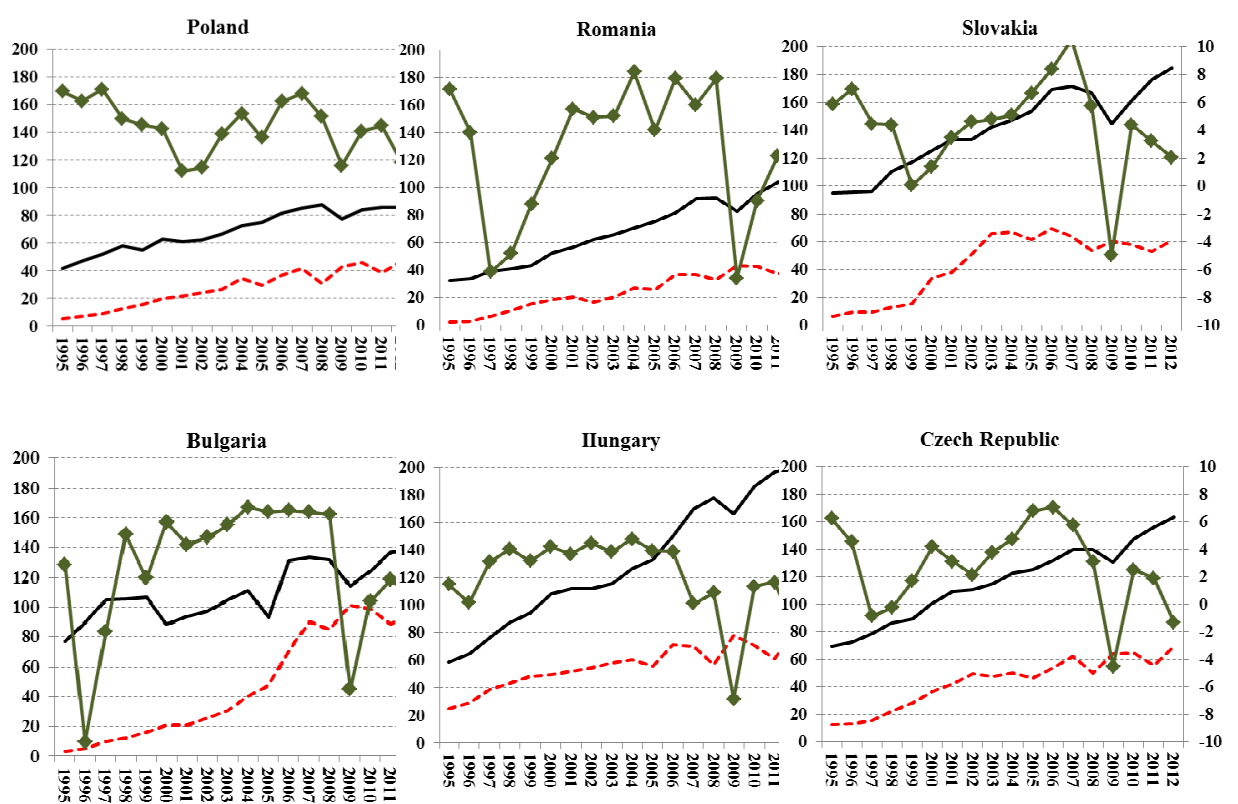

— Trade openness ( $\%$ of GDP) - - - - Financial openness ( $\%$ of GDP)

$\longrightarrow$ Economic growth (right scale, \%)

Sources: Eurostat Database and authors calculations.

Table 1 reports the results of estimating different versions of equation (1), using static panel data methods. First, simple static panel regressions are conducted in order to test the impact of trade openness on economic growth using both fixed and random effects estimators. The analysis starts with the inclusion of only the degree of openness as an explanatory variable, measured by the ratio of imports and exports to GDP, along with a dummy variable in order to capture the effects of the economic and financial crisis. As model 1 estimation results show, both the coefficient of the trade variable and the dummy variable are statistically significant, the coefficient of the trade measure of openness revealing a positive impact on economic growth. In order to check the robustness of the results the Hausman test is computed and it seems to favour the fixed effects model estimator. Also the Breusch Pagan test states that there seems no evidence of significant differences across countries, therefore there is no need for including random effects. This is also the reason why the table contains only the estimations from the fixed effects models, as Breusch Pagan test did not indicate the necessity of including random effects in neither of the cases.

Excluding the trade share and including another measure of the degree of openness, namely the share of FDI to GDP yields different results as model 2 shows. More specific, the constant and the dummy variable are still significant, while the coefficient of the financial variable, although positive, is statistically insignificant.

In order to obtain a more complete measure of the degree of openness, the ratio of foreign direct investments to GDP along with the trade variable is considered and then the same static panel data estimation is conducted. The foreign direct investments stock is included with one lag, taking into considerations that the spillovers related to the FDI stock impact economic activity with some delay. In this case (model 3), the coefficient of the financial variable is positive and 
statistically significant at 5 percent level, while the one of the commercial variable is slightly negative. The dummy variables and the constant have significant coefficients.

Table 1: Effects of Trade and Financial Openness on Economic Growth. Static Panel Data Estimates

\begin{tabular}{|l|c|c|c|c|c|c|}
\hline \multicolumn{1}{|c|}{ Model } & $\mathbf{1}$ & $\mathbf{2}$ & $\mathbf{3}$ & $\mathbf{4}$ & $\mathbf{5}$ & $\mathbf{6}$ \\
\hline $\begin{array}{l}\text { Constant } \\
\text { (standard error) }\end{array}$ & $\begin{array}{c}-2.75 \\
(1.18)^{* *}\end{array}$ & $\begin{array}{c}2.88 \\
(0.58)^{*}\end{array}$ & $\begin{array}{c}4.94 \\
(1.27)^{*}\end{array}$ & $\begin{array}{c}0.22 \\
(1.71)\end{array}$ & $\begin{array}{c}0.57 \\
(0.91\end{array}$ & $\begin{array}{c}1.81 \\
(1.68)\end{array}$ \\
\hline $\begin{array}{l}\text { Trade Openness } \\
\text { (standard error) }\end{array}$ & $\begin{array}{c}0.05 \\
(0.012)^{*}\end{array}$ & - & $\begin{array}{c}-0.03 \\
(0.01)^{* * *}\end{array}$ & $\begin{array}{c}0.02 \\
(0.14)\end{array}$ & - & $\begin{array}{c}-0.016 \\
(0.02)\end{array}$ \\
\hline $\begin{array}{l}\text { Dummy*Trade openness } \\
\text { (standard error) }\end{array}$ & $\begin{array}{c}-0.03 \\
(0.0107)^{*}\end{array}$ & - & $\begin{array}{c}0.03 \\
(0.02)^{* * *}\end{array}$ & $\begin{array}{c}-0.02 \\
(0.01)^{*}\end{array}$ & - & $\begin{array}{c}0.032 \\
(0.02)\end{array}$ \\
\hline $\begin{array}{l}\text { Dummy*Financial openness } \\
\text { (standard error) }\end{array}$ & - & -0.07 & -0.15 & - & -0.076 & -0.14 \\
$(0.01)^{*}$ & $(0.05)^{*}$ & $-0.01)^{*}$ & $(0.048)^{*}$ \\
\hline $\begin{array}{l}\text { Financial Openness (-1) } \\
\text { (standard error) }\end{array}$ & - & 0.02 & 0.056 & - & 0.047 & 0.06 \\
\hline $\begin{array}{l}\text { External demand (-1) } \\
\text { (standard error) }\end{array}$ & - & - & - & 0.54 & $0.01)^{*}$ & $(0.02)^{* *}$ \\
\hline Time effects & No & No & No & No & 0.56 \\
\hline Fixed effects & YES & YES & YES & YES & YES & YES \\
\hline $\begin{array}{l}\text { Hausman test } \\
\text { (prob>chi2) }\end{array}$ & 9.69 & 0.96 & 3.31 & 0.9 & 1.22 & 0.7 \\
\hline $\begin{array}{l}\text { Breusch Pagan test for } \\
\text { random effects } \\
\text { (prob>chi2) }\end{array}$ & 0.0079 & 0.61 & 0.5 & 0.82 & 0.74 & 0.98 \\
\hline R-sq & 2.07 & 0.67 & 1.46 & 0.05 & 0.81 & 1.16 \\
\hline F test/Wald test & 0.1498 & 0.41 & 0.22 & 0.83 & 0.37 & 0.28 \\
\hline Prob>F/chi2 & 0.1536 & 0.1395 & 0.1745 & 0.1935 & 0.274 & 0.293 \\
\hline Number of observations & 11.25 & 8.59 & 21.13 & 6.96 & 10.95 & 7.05 \\
\hline
\end{tabular}

Notes: *significant at 1 percent level, ${ }^{* *}$ significant at 5 percent level, ${ }^{* * *}$ significant at 10 percent level.

Going further, other control variables are included in order to better explain economic growth, namely a measure of external demand and the real exchange rate. In all cases the real exchange rate had insignificant coefficients and it did not bring any additional information to the model as R-squared did not improve therefore it was eliminated from all specifications.

Firstly, for the extended model static panel estimation is used, afterwards the Hausman test and Breusch Pagan test are computed. The economic growth in EU is used as a proxy for the external demand and it is included with one lag in the equation. Model 4 comprises the trade share and external demand along with the dummy variable. The coefficient of the trade share is positive, although insignificant, while external demand has a positive and significant coefficient of 0.54 . Replacing the trade share with the financial variable, namely the share of FDI stock to GDP reveals a positive and statistically significant coefficient for the FDI, of almost 0.05 , while external demand still has a positive, although higher, effect of 0.6. The final step consists of including both measures of the degree of openness along with the external demand as indicated by model 6. The financial variable has a positive and significant at 5 percent level coefficient of 0.06 , while the trade share has a negative and insignificant coefficient.

Table 2 reports the dynamic panel data estimates obtained by using the Arellano Bond method with one period lag. The main reason for using the dynamic panel data estimator is due to the fact that according to the Hausman test in most of the cases, the fixed effects model is better 
suited for the previously analysed specifications, while in some cases the results are not conclusive, this being the reason for computing an additional test, namely the Breush Pagan test for assessing the potential random effects which seems to reject this hypothesis in most of the cases. Therefore, by admitting the existence of time invariant characteristics (fixed effects) one needs to consider the fact that they may be correlated with the explanatory variables. The fixed effects may be contained by the error term in equation 1 that usually consists of the unobserved country specific effects. By transforming the term by first difference the fixed effects country specific is removed because this kind of effects as previously mentioned do not vary with time. For instance equation (1) when using the Arellano Bond estimator is transformed into:

$\Delta \mathrm{GDP}_{\mathrm{i}, \mathrm{t}}=\alpha_{1} \cdot \Delta \operatorname{trade}_{\mathrm{i}, \mathrm{t}}+\alpha_{2} \cdot \Delta \mathrm{fdi}_{\mathrm{i}, \mathrm{t}}+\alpha_{3} \cdot \Delta \operatorname{control}_{\mathrm{i}, \mathrm{t}}+\Delta \varepsilon_{\mathrm{i}, \mathrm{t}}$

The fixed effects are contained by $\varepsilon_{\mathrm{i}, \mathrm{t}}$ that consists of unobserved country specific effects, $v_{\mathrm{i}}$ and the specific errors of the observations, $\mathrm{u}_{\mathrm{i}, \mathrm{t}}$.

$\varepsilon_{\mathrm{i}, \mathrm{t}}=v_{\mathrm{i}}+\mathrm{u}_{\mathrm{i}, \mathrm{t}}$

When differencing for the Arellano Bond estimator the fixed effects are removed and equation (6) is transformed into:

$\varepsilon_{\mathrm{i}, \mathrm{t}}-\varepsilon_{\mathrm{i}, \mathrm{t}-1}=\mathrm{u}_{\mathrm{i}, \mathrm{t}}-\mathrm{u}_{\mathrm{i}, \mathrm{t}-1}$

Using the Arellano Bond estimator any endogeneity problem is therefore eliminated; these endogeneity issues may appear, either from fixed effects included in the previous estimation, either from the fact that the influences between the dependent variable and the explanatory factors may run in both directions. Table 2 therefore reports the results obtained by using dynamic estimation with one period lag for all the models previously described. What is interesting to point is that, although in the static panel framework there were some specifications indicating a negative coefficient for certain measures of the degree of openness, when using the dynamic estimation, all the models indicate positive impacts of both trade share and financial openness, although in some cases (e.g. model 6) the effects are statistically insignificant. The magnitude of the commercial variable ranges between 0.013 in model 1 to 0.02 in model 3 , while the share of FDI in GDP has a higher impact on economic growth reaching 0.1 in model 2 . In order to check the validity and robustness of the results, the Sargan test is employed and the validity of the instruments is assessed. In all cases, the instruments are valid. 
Table 2: Effects of Trade and Financial Openness on Economic Growth. Dynamic Panel Data Estimates

\begin{tabular}{|l|c|c|c|c|c|c|}
\hline \multicolumn{1}{|c|}{ Model } & $\mathbf{1}$ & $\mathbf{2}$ & $\mathbf{3}$ & $\mathbf{4}$ & $\mathbf{5}$ & $\mathbf{6}$ \\
\hline $\begin{array}{l}\text { Economic growth (-1) } \\
\text { (standard error) }\end{array}$ & $\begin{array}{c}0.438 \\
(0.052)^{*}\end{array}$ & $\begin{array}{c}0.485 \\
(0.06)^{*}\end{array}$ & $\begin{array}{c}0.42 \\
(0.06)^{*}\end{array}$ & $\begin{array}{c}0.39 \\
(0.089)^{*}\end{array}$ & $\begin{array}{c}0.338 \\
(0.10)^{*}\end{array}$ & $\begin{array}{c}0.38 \\
\left(0.09^{*}\right)\end{array}$ \\
\hline $\begin{array}{l}\text { Trade Openness } \\
\text { (standard error) }\end{array}$ & $\begin{array}{c}0.013 \\
(0.003)^{*}\end{array}$ & - & $\begin{array}{c}0.02 \\
(0.007)^{*}\end{array}$ & $\begin{array}{c}0.014 \\
(0.003)^{*}\end{array}$ & - & $\begin{array}{c}0.01 \\
(0.01)\end{array}$ \\
\hline Financial Openness (-1) & - & 0.1 & 0.09 & - & 0.03 & 0.009 \\
(standard error) & - & $(0.034)^{*}$ & $(0.032)^{*}$ & - & $(0.009)^{*}$ & $(0.02)$ \\
\hline $\begin{array}{l}\text { External demand (-1) } \\
\text { (standard error) }\end{array}$ & - & - & - & 0.1 & 0.22 & 0.14 \\
\hline Wald test & 136.54 & 87.41 & 122.89 & 96.18 & 48.93 & 96.03 \\
\hline Prob>chi2 & 0 & 0 & 0 & 0 & 0 & 0 \\
\hline Number of instruments & 155 & 139 & 161 & 116 & 92 & 117 \\
\hline Sargan test & 159.0034 & 163.75 & 142.34 & 117.38 & 104.44 & 116.84 \\
p value & 0.3532 & 0.052 & 0.23 & 0.3699 & 0.12 & 0.38 \\
\hline Number of observations & 126 & 114 & 114 & 96 & 96 & 96 \\
\hline
\end{tabular}

Notes: *significant at 1 percent level, ${ }^{* *}$ significant at 5 percent level, ${ }^{* * *}$ significant at 10 percent level.

In order to better explain economic growth, as in the static panel version, in the dynamic panel data estimations is included as a control variable a measure of external demand (models 4 to 6). Although both variables measuring the degree of openness have positive and significant coefficients, external demand has no more a significant impact on the economic growth of CEE countries.

\section{Output Comovement: Stylized Facts}

In order to measure comovements between Central and Eastern European countries (CEE countries) and European Union (EU), two different methods based on quarterly real GDP in local currency prices were chosen. First, the simplest and most common measure of output comovements is used, represented by the correlation of real GDP growth between every analysed economy and EU (Figure 2 shows a comparison of output comovements using this measure). To this purpose, fixed spans, rolling window of two or five years long time period and an instantaneous measure were used. The economic growth rates correlations had been reduced as magnitude in the years before the crisis but increased significantly during the crisis period. The phenomenon was observed in case of all regions, including emerging and developing economies, not being specific only to advanced economies where financial crisis originated. Since 2010 correlations between different countries and regions have fallen back significantly which suggest that the global economic evolution, including CEE countries, have returned to a normal state of nature. The understanding of the factors that drove the changes in comovements is essential in order to anticipate if the comovements could increase markedly again. It is possible that the increase in output growth correlations was determined by significant shocks which affected simultaneously many economies, such as a sudden rise of financial uncertainty or a change in the investors' perceptions regarding their placements (Fratzscher (2012); Acharya and Schnabl (2010); and Bekaert et al. (2011)). Alternatively, IMF (2013) suggested that at the origin of this increase could be the output spillovers (i.e. the transmission of country specific shocks to other economies, affecting the economic growth regionally or even globally) which increased in importance due to the intensification of financial and trade linkages. 


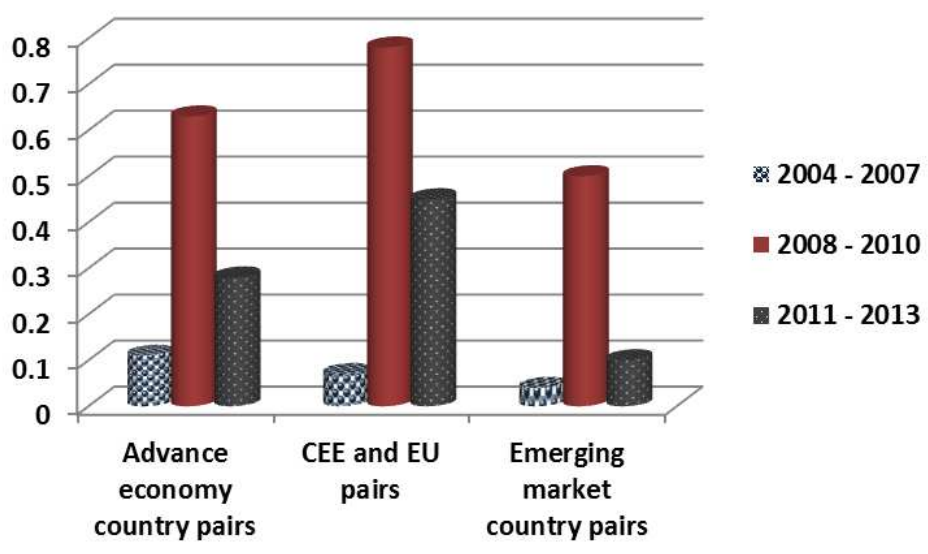

Figure 2: Growth rate correlations

Sources: Eurostat Database; IMF, World Economic Outlook; Organization for Economic Cooperation and Development; and author calculations.

The second method follows Giannone, Lenza, and Reichlin (2008), who measure business cycle synchronization with the negative of divergence, computed as the absolute value of real GDP growth differences between each CEE country and EU in every year included in the sample:

$\mathrm{SYNCH}_{\mathrm{i}, \mathrm{ea}, \mathrm{t}}=-\left|\left(\ln \mathrm{Y}_{\mathrm{i}, \mathrm{t}}-\ln \mathrm{Y}_{\mathrm{i}, \mathrm{t}-1}\right)-\left(\ln \mathrm{Y}_{\mathrm{ea}, \mathrm{t}}-\ln \mathrm{Y}_{\mathrm{ea}, \mathrm{t}-1}\right)\right|$

This indicator is simple and in contrast to the correlation measures it does not contain estimation errors being insensitive to various filtering methods that have been criticized by Canova (1998) among others or to the time length of the rolling window used in the computation.

The averages of five-year rolling window growth correlations across each EEC and rest of the EU country pair remained contained below 0.7 from the 2000 Q1 until 2008 Q2. The five-year moving average growth correlations spiked sharply during the global financial crisis, starting with 2008 Q3 (Figure 3). Following the onset of the global crisis in September 2008, there was a sharp and synchronized collapse in output in 2008 Q4 and 2009 Q1. This event led to a sharp rise in growth correlations, towards values around 0.8 for all country pairs considered in the analysis, with the highest correlations observed among pairs including Czech Republic, Hungary, Lithuania and Romania on one side and the rest of EU on the other one. The correlations based on output gap measures show even higher increase during the economic crisis.

The five-year rolling window correlations suggest that output synchronization remains high, but if the output comovements is computed using a shorterwindow or instantaneous correlations it can be observed that they have already been fallen. In case of two-year rolling window, where growth correlations are used, there is a significant decrease in output comovements in 2011 Q1 (Figure 4). This drop coincides with the moment when the first quarter of 2009 exits out of the two-year rolling window. Also an instantaneous measure of correlation was used in order to test that average output comovements sharply decreased compared to the peak of the global financial crisis.

The instantaneous measure of correlation is defined in the following way:

$$
\frac{\left(\Delta \mathrm{y}_{\mathrm{i}, \mathrm{t}}-\overline{\Delta \mathrm{y}_{\mathrm{i}}}\right) \cdot\left(\Delta \mathrm{y}_{\mathrm{j}, \mathrm{t}}-\overline{\Delta \mathrm{y}_{\mathrm{i}}}\right)}{\sigma_{\mathrm{i}} \cdot \sigma_{\mathrm{j}}}
$$


Although this measure is similar to a correlation index, it is not bounded between -1 and 1 because, if growth rates in the two countries/regions included in the pair are both far away from their

\section{Figure 3: The five-year moving average} growth rate correlations

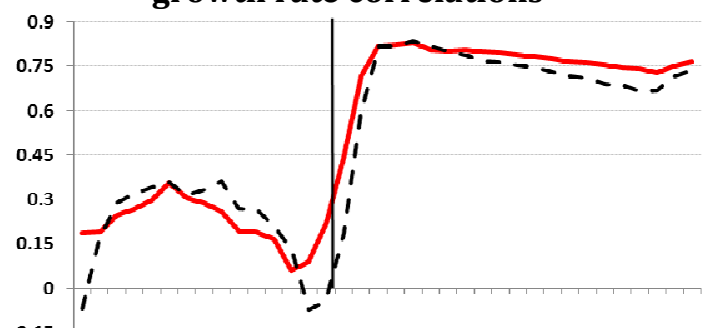

0.15

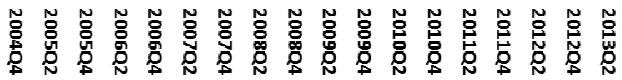

Five year rolling window growth rate correlations across $\mathrm{CEE}$ countrles and EU (average)

- - Five year rolling window growth rate correlations between Romania and EU respective means, as happened during the peak of the financial global crises, this correlation measure can significantly exceed 1.

Figure 4: The two-year moving average growth rate correlations
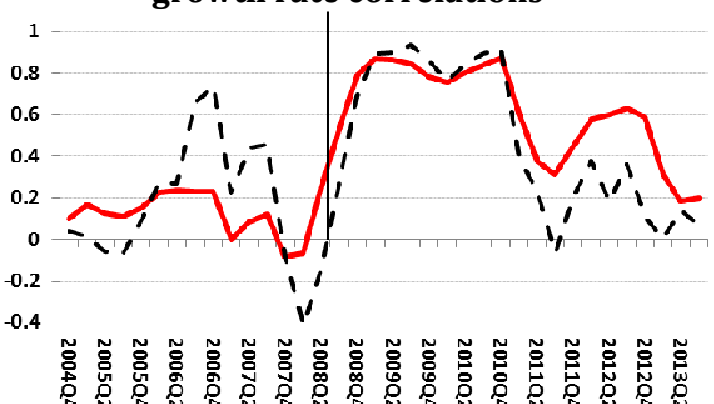

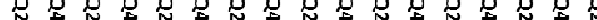

Two year rolling window growth rate correlations across CEE countries and EU (average)

- Two year rolling window growth rate correlations between Romania and EU

Sources: Eurostat Database and authors calculations.

As it can be observed from Figure 5, the output growth correlations after 2011 have fallen close to pre-crisis levels, in spite of the intensification of the sovereign debt crisis in Europe during this period.

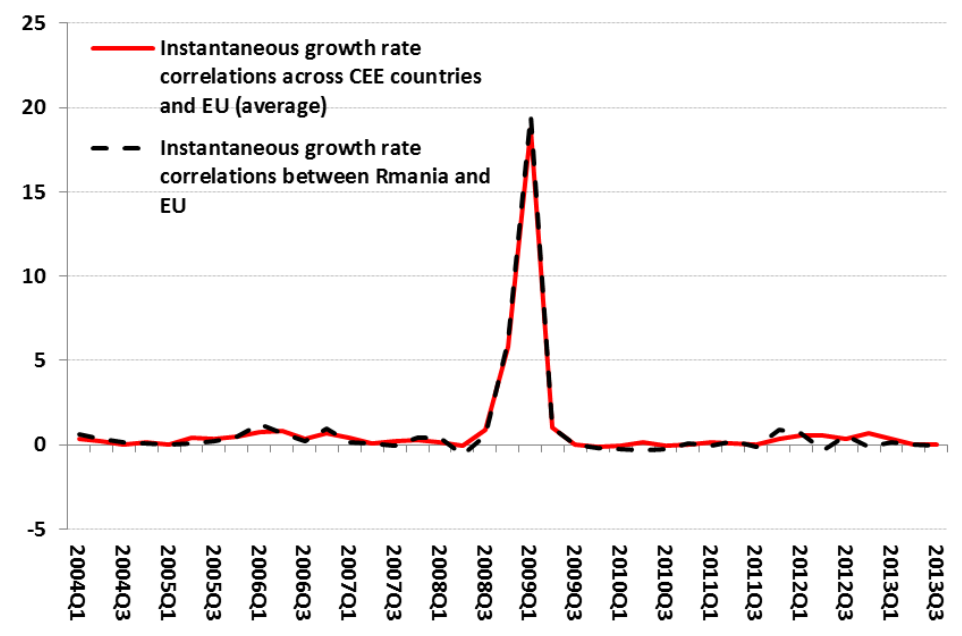

Figure 5: The instantaneous growth rate correlations

Sources: Eurostat Database and authors calculations. 
The role of financial and trade linkages in transmission of shocks on output comovements

In order to test the role of financial and trade linkages in transmission of shocks on output comovements the panel model described in equation (4) was estimated. The Hausman test conducted on these estimations indicates the utilization of fixed effects model estimator.

The estimation results indicate that during normal times, an increase in financial flows between different regions tends to lower comovements between them (Table 3, models 2 to 4). The coefficient corresponding to the financial channel is econometrically and statistically significant. The sign of the coefficient is negative suggesting that increased financial flows determine a decreasing of economic growth synchronization during normal times. If financial channel is active and the economy operates in normal conditions, investors tend to diversify the placements looking for the regions were the capital is more productive.

The results are in line with relevant literature, which indicate that financial integration rises risk sharing and tend to decrease the volatility in consumption (for example, Bekaert, Campbell, and Lundbad (2011) or Kalemli-Ozcan, Sorensen, and Yosha (2003), among others). However, during crisis the way in which the financial channel is working is changing due to the fact that financial shocks are transmitted through financial linkages. Regions that experience a high degree of integration, especially through the banking system, had a significant increase in their economic growth comovement during the crisis period. Although the financial channel allows efficient capital allocation in normal conditions, during crisis it facilitates the transmission of the financial shocks across different regions. The total effect of financial linkages on output comovement is negative but its effect during the global crisis from 2008 - 2009 was reversed, becoming positive, as the sign of the coefficient corresponding to financial linkages multiplied with dummy variable indicate (models 2 and 3). However, the total effect is still negative suggesting that the crisis weakened the negative relationship between financial integration and output comovement.

Table 3: Comovements and Trade and Financial linkages between CEE countries and EU

\begin{tabular}{|l|c|c|c|c|c|}
\hline \multicolumn{1}{|c|}{ Model } & $\mathbf{1}$ & $\mathbf{2}$ & $\mathbf{3}$ & $\mathbf{4}$ & $\mathbf{5}$ \\
\hline $\begin{array}{l}\text { Dummy variable for } \\
\text { crisis period }\end{array}$ & $\begin{array}{c}-2,09 \\
(-4,10)^{*}\end{array}$ & $\begin{array}{c}-0,85 \\
(-2,06)^{* *}\end{array}$ & $\begin{array}{c}-2,92 \\
(-1,71)^{* * *}\end{array}$ & $\begin{array}{c}-0,72 \\
(-2,08)^{* * *}\end{array}$ & $\begin{array}{c}-0,45 \\
(-3,49)^{*}\end{array}$ \\
\hline Trade Linkages & $\begin{array}{c}0,006 \\
(2,64)^{*}\end{array}$ & & $\begin{array}{c}0,008 \\
(5,46)^{*}\end{array}$ & $\begin{array}{c}0,009 \\
(6,26)^{*}\end{array}$ & $\begin{array}{c}0,007 \\
(2,88)^{*}\end{array}$ \\
\hline $\begin{array}{l}\text { Trade Linkages } \\
\times \text { Dummy }\end{array}$ & $\begin{array}{c}0,017 \\
(3,39)^{*}\end{array}$ & & $\begin{array}{c}0,024 \\
(1,55)^{* * *}\end{array}$ & & \\
\hline Financial Linkages & & $\begin{array}{c}-0,015 \\
(-3,45)^{*}\end{array}$ & $\begin{array}{c}-0,013 \\
(-2,56)^{*}\end{array}$ & $\begin{array}{c}-0,01 \\
(-2,57)^{*}\end{array}$ & \\
\hline Financial Linkages \\
$\times$ Dummy & & $\begin{array}{c}0,022 \\
(0,83)^{* * *}\end{array}$ & $\begin{array}{c}0,01 \\
(0,36)^{* * *}\end{array}$ & & \\
\hline Fixed effects & YES & YES & YES & YES & YES \\
\hline Observations & 228 & 228 & 228 & 228 & 228 \\
\hline R Squared & 0,25 & 0,2 & 0,25 & 0,2 & 0,2 \\
\hline
\end{tabular}

Bogdan Murarașu and Alina Bobașu (2015), Journal of Eastern Europe Research in Business and Economics, DOI: $10.5171 / 2015.460151$ 
Note: This table reports panel (CEE countries with EU pairs) fixed-effect estimates for the period 2004 Q1 - 2013 Q3 using 6 country pairs. Slovakia was excluded from the panel due to data availability issues regarding direct investments quarterly flows having as partner EU27 countries. The dependent variable is the comovement of real GDP growth between each CEE country and EU measured using the instantaneous synchronization index. The results are not changing sensible when the comovement measure is changed with one of the different alternatives described earlier in the paper. The dummy variable for the crisis equals 1 during the 2008 Q3 2009Q2 interval and 0 everywhere else. Trade linkages are measured by the bilateral real exports and imports of each country and EU expressed as a share of real GDP. Financial linkages are measured by the bilateral real foreign direct and portfolio investments flows of each country and EU expressed as a share of real GDP. In parenthesis are reported $T$ statistics. ${ }^{*}, * *$, ***, denote significance at the 1 percent, 5 percent and 10 percent levels, respectively.

The crisis dummy captures a significant part of the spike in synchronization coefficient, indicating that there are some other factors, apart from the financial and trade linkages, which contributed to spreading of the negative effects of the crisis affecting the synchronized output fall in the analysed economies. Bacchetta and van Wincoop (2013) suggested that global panic and self-fulfilling expectations significantly contributed to the spread of the negative effects of the global financial crisis.

The measured influence of trade linkages is significantly more reduced compared with the impact of financial linkages also due to the limited time variation in quarterly trade data relative to financial data (see model 5 for example).

\section{Conclusion}

Recent macroeconomic literature has paid much attention to studying the effects of commercial and financial openness on economic growth. However, scant empirical studies devoted their work to analysing this phenomenon in Central and Eastern European countries.

Therefore this paper brings a contribution to this literature by studying the relationship between the degree of openness and economic growth in seven emerging economies from Central and Eastern European countries using both static and dynamic panel data estimation methods. The results point towards a positive contribution of international trade and foreign direct investments on economic growth although the magnitude and the significance of the impact depend on the estimation method and also on the control variables we include in order to provide a better explanation of the real economic growth.

However, the trade and financial linkages may significantly contribute to the transmission of negative shocks from more developed economies towards emerging countries and significant synchronized GDP fall may emerge.

The main findings indicate that higher financial integration tends to reduce output synchronization during normal economic conditions while during crises periods the regions which are more financially linked experience greater synchronization.

Preserving financial stability is essential in order to prevent synchronized GDP growth collapses in many countries. The transmission mechanism of financial shocks on economic growth synchronization during normal periods is substantially different than during crisis. If during normal periods the capital flows are channelized towards emerging markets which offer greater yields determining output divergence within regions with strong financial linkages, during crisis the financial channels favours the propagation of adverse shocks contributing to output fall synchronization. That is way it is important to safeguard the benefits of financial integration through minimizing consequent risks by the instrumentality of better prudential oversight and policy 
coordination across the entire international financial system.

\section{Acknowledgment}

"This paper was co-financed from the European Social Fund, through the Sectorial Operational Programme Human Resources Development 2007-2013, projects numbers: POSDRU/159/1.5/S/138907 "Excellence in scientific interdisciplinary research, doctoral and postdoctoral, in the economic, social and medical fields -EXCELIS" and POSDRU/159/1.5/S/134197 "Performance and excellence in doctoral and postdoctoral research in Romanian economics science domain", coordinator The Bucharest University of Economic Studies"

\section{References}

1. Acharya, Viral V. and Schnabl, P. (2010), 'Do Global Banks Spread Global Imbalances? Asset-Backed Commercial Paper during the Financial Crisis of 200709,' IMF Economic Review, 58(1), 37-73.

2. Auerbach, A. and Gorodnichenko, Y. (2013), 'Output Spillovers from Fiscal Policy,' American Economic Review, 103(3),141-46.

3. Bacchetta, P. and van Wincoop, E. (2013), 'Sudden Spikes in Global Risk,' Journal of International Economics, 89(2), 511-21.

4. Bajwa, S. and Siddiqi, M. (2011), 'Trade openness and its effects on economic growth in selected South Asian Countries: A Panel Data Study,' World Academy of Science, Engineering and Technology.

5. Beetsma, R., Giuliodori, M. and Klaassen, F. (2006), 'Trade Spillovers of Fiscal Policy in the European Union: A Panel Analysis,' Economic Policy, 21(48), 639-87.

6. Bekaert, G., Campbell, H.R. and Lundblad, C. (2011), 'Financial Openness and Productivity,' World Development, 39( 1), 1-19.
7. Canova, F. (1998), 'Detrending and Business Cycle Facts,' Journal of Monetary Economics, 41(.3), 475-512.

8. Chang, R., Kaltani, L. and Loayza, N. (2009),'Openness is good for economic growth: The role of policy complementaries,' Journal of Developed Economics, 90, 33-49

9. Claessens, S., Tong, H. and Zuccardi, I. (2012), 'Did the Euro Crisis Affect Nonfinancial Firm Stock Prices through a Financial or Trade Channel?,' IMF Working Paper No. 11/227 (Washington: International Monetary Fund).

10.di Giovanni, J. and Shambaugh, J.C. (2008), 'The Impact of Foreign Interest Rates on the Economy: The Role of the Exchange Rate Regime,' Journal of International Economics, 74 (2), 341-61.

11.Frankel, J. and Rose, A.(1998), 'The Endogeneity of the Optimum Currency Area Criteria,' Economic Journal, 108( 449), pp. 1009-25.

12.Fratzscher, M. (2012), 'Capital Flows, Push versus Pull Factors and the Global Financial Crisis,' Journal of International Economics,88(2), pp. 341-56.

13.Giannone, D., Lenza, M. and Reichlin, L. (2010), 'Did the Euro Imply More Correlation of Cycles?' in Europe and the Euro, ed. by Alberto Alesina and Francesco Giavazzi (Chicago: University of Chicago Press), 141-67.

14.Grossman, G.M. and Helpman, E. (1991), 'Trade, knowledge spillovers and growth', NBER Working Paper 3485.

15.International Monetary Fund (2013),'World Economic Outlook, Transitions and Tensions', October 2013, http://www.imf.org/external/pubs/ft/we o/2013/02/.

16.Kalemli-Ozcan, S., Sorensen, B.E. and Yosha, O. (2003), 'Risk Sharing and Industrial Specialization: Regional and International Evidence,' American Economic Review, 93( 3), 903-18. 
17.Kalemli-Ozcan, S., Papaioannou, E. and Perri, F. (2013), 'Global Banks and Crisis Transmission,' Journal of International Economics, 89, 495-510.

18.Kalemli-Ozcan, S., Papaioannou, E. and Peydro-Alcalde, J.L. (2009), 'Financial Integration and Risk Sharing: The Role of Monetary Union, in The Euro at Ten: Fifth European Central Banking Conference, ed. by Bartosz Maćkowiak, Francesco Paolo Mongelli, Gilles Noblet, and Frank Smets (Frankfurt: European Central Bank).

19.Rodriguez, $\mathrm{F}$ and Rodrick, D. (2001),'Trade Policy and economic growth: A Skeptic's Guide to the Cross-National Evidence' NBER Macroeconomics Annual 2000, 15, MIT Press, 26y1-325.
20.Romer, D. (1993),'Openness and inflation. Theory and evidence' Quarterly Journal of Economics 108 (November), 869903.

21.Ulasan, B. (2012), 'Openness to international trade and economic growth: A cross-country empirical investigation' Central Bank of the Republic of Turkey, Discussion Paper.

22.Yanikkaya, H. (2003),'Trade openness and economic growth: a cross-country empirical investigation', Journal of Development Economics, 72, 57-89.

23.Zeren, F. and Ari, A. (2013),'Trade openness and economic growth: A panel causality test,' International Journal of Business and Social Science, 4(9). 